\title{
HUMANITARIAN ACTION - A SOURCE OF OPTIMISM FOR THE INTERNATIONAL ORDER OF THE FUTURE
}

\author{
Otto Hieronymi \\ Head, Program of International Relations and Migration and Refugee Studies, \\ Webster University, Geneva
}

\section{INTRODUCTION}

Humanitarian action, like human rights, has become an important dimension of international relations. There are both negative and positive reasons for this development:

1. The extent and violence of the crises and the reluctance to deal with the root causes, and;

2. The reaction of the international community coming to the aid of the victims of the so-called "humanitarian crises".

There has to be a realization today that humanitarian action brings not only shortterm relief and protection for the victims of man-made or natural disasters, but is also in the interests of those providing aid and protection by strengthening social and political cohesion, and it can have a major positive impact on the outlook for international order. Humanitarian action - providing relief and protection for the victims - has come to be recognized as an important component of international relations and of international order. This is shown by the multiplication of actors and by the broadening of the concept to include the responsibility to protect.

The global concept of the international "responsibility to protect" is an important manifestation of this trend. It has been one of the principal positive developments of recent years. It reflects the general reaction of the public that "something has to be done" by the "international community" faced with the persistence of protracted crises and suffering or confronted with the destruction brought about by sudden man-made or natural disasters.

There is a close link between the nature and quality of international order and humanitarian action. This is a "two-way" relationship where international order influences the need for and the conditions under which humanitarian action takes place, while at the same time humanitarian action also has a direct and indirect impact on the working of international order.

The central thesis of this paper is that there is a positive relationship between humanitarian action and international order. In other words, humanitarian action is not only a positive manifestation of international order, but humanitarian action can have a positive long-term impact on international order.

Humanitarian action brings benefits not only to the victims or potential victims but also to those who provide the protection and relief to the victims - i.e. 
individual humanitarian workers, the various organizations to which they may belong as well as the broader communities, national or international ${ }^{1}$.

\section{HUMANITARIAN ACTION AND POLITICAL ORDER}

One of the principal interests of this series of annual conferences has been the fact that most of the speakers (and there have been several hundred by now) have succeeded both to convey their experience, work and views related to specific aspects of the humanitarian field and to set these specific issues in a broader perspective.

The objective of the Webster conferences has not been to discuss the political, economic or security situation in the different parts of the world and the origins of the political crises that have had such devastating humanitarian consequences during the last fifteen years. The focus was on the humanitarian issues - how can we help, how can we bring relief, how can we protect the victims.

However, the background against which humanitarian issues were discussed during these meetings from the start and throughout the last ten years, was the question of domestic and international political order. The conclusion one can reach through observing the developments of the last ten years and through perusing the papers presented at these conferences is that humanitarian action contributes to a better international order. This conclusion may not sound original and it may be one that we all expect, yet it is still one that does not receive sufficient attention not only in the political debate and practice but also among experts, including the humanitarians.

One of the most dramatic lessons of the last hundred years in general and of the last decades of the $20^{\text {th }}$ century is the recognition of the close connection between political order and humanitarian crises. The analysis of this link, of the causality usually goes in one direction: what types of political conditions cause humanitarian crises.

At the domestic level, two extreme type of political systems or conditions have been responsible for the bulk of the "humanitarian crises" - oppressive (authoritarian or totalitarian states) on the one hand, and weak, disintegrating or failed states, on the other hand. At the international level the main factors of influence have been not so much the lack of rules or the lack of means but rather the indifference of the international community, to provide and to use the means necessary to prevent or to deal with actual or potential developments that lead to humanitarian crises.

\section{THE EXPANDING SCOPE OF HUMANITARIAN ACTION}

During the last fifteen years humanitarian action has become an important dimension of international relations. The concept of humanitarian action has been expanded, to include the "responsibility to protect" and there has been a multiplication of actors. The increased importance of humanitarian action has been the result of the extent of the crises and the suffering and of the concerted reaction at all levels of the international community. 
Humanitarian action at all levels at all times is an expression of solidarity with actual or potential victims. Thus, international humanitarian action is an expression of international solidarity with countries, groups and first and foremost with individuals independently of their nationality. The definition of humanitarian action adopted at these conferences has been a broad one.

In the first place, it covers, of course, relief and protection of victims of war and persecution - the essence of the traditional definition as it has developed since the second half of the $19^{\text {th }}$ century. It includes also the victims of natural disasters which often are also the result at least in their extent of human neglect or of lack of resources. The definition also extends to both prevention and deterrence of crimes against humanity. The expanding concept of humanitarian action includes relief and protection - for the human person - independently of his or her nationality. The newly defined international "responsibility to protect" covers: prevention and deterrence of crimes against humanity, intervention, if necessary, to stop the perpetrators, sanctioning them, as well as reconstruction and reconciliation. It is clear that the quality of domestic and political and social order is recognized as a major issue both in the origins of humanitarian crises and among the objectives to help prevent future crises.

Today's "humanitarian landscape" is broad and complex. The role of each of the major traditional categories of actors has further expanded: of the nongovernmental organizations which traditionally assumed most of the direct work (to a large extent through volunteers) and responsibility in humanitarian action and which even today continue to do so; of the international organizations outside and inside the UN system; and of the governments and government agencies which today finance the bulk of humanitarian action - their own, the action of NGOs and international organizations. At present we can add a new category of actors: the private sector.

The increased number of actors engaged in humanitarian action is not a problem but a positive development. The issue is not whether any organization or category of organization can claim a monopoly on the concept but to see what do they bring to this field beyond their involvement in specific isolated actions. The multiplication of the number of actors in each category - NGOs, government agencies and international organizations - directly or indirectly involved in humanitarian action is a clear recognition of the increased importance of humanitarian action.

If there is an ongoing and often lively debate about mandates, about cooperation, about coordination and division of tasks, about accountability and the efficiency of humanitarian action, there is also a broad consensus that this diversity and multiplicity of people and organizations engaged in the "humanitarian area" are a sign of increasingly global concern with the consequences of war and violence and persecution.

The expansion of humanitarian action has been the result of two closely interdependent developments: the magnitude of the crises and of the suffering and the sensation that, even if not directly involved, we are somehow all affected.

One of the most important questions about the outlook in our globalized world is whether this solidarity with the victims is only "the effect of the media", 
a fleeting superficial phenomenon, or does it reflect a fundamental and lasting change for the better in international order?

The increased engagement of the states in humanitarian action - both through their financial and other resources and through attempts at coordination and priority setting - also contains certain risks. Some go as far as saying that states are tempted to "hijack" the very concept of humanitarianism for partisan or political motives. Others point out that the resources provided by states for humanitarian action during the last fifteen years reflected their unwillingness to undertake political and security measures to help prevent or stop the conflicts and crises that often involved major crimes against humanity - that subsequently dubbed as "humanitarian emergencies". It is also argued that the blurring of the distinction between state action and humanitarian action may create confusion in the field and expose humanitarians to danger. Also, the growing weight of government can lead to bureaucratisation and banalization of humanitarian action and misallocation of scarce resources (e.g. as a result of excessive use of "earmarking" funds for selected crises). Finally, "management through across-board budget-cutting" - a favourite approach of many national administrations and parliaments - contributes to shortages of financial and human resources.

On the whole, the active participation and cooperation of the various groups of actors is a source of strength rather than a weakness of contemporary humanitarian action - provided that the presence of the state and of the private sector does not weaken the recognition of the need for neutral and independent humanitarians.

The principal benefits, both for those who receive relief and protection and for those who provide it, of the expanding concept of humanitarian action can be briefly summed up. For the actual and potential victims of violence and persecution these are: relief and protection, and in many cases their very survival; human dignity; return to normalcy; restoring values; belief in humanity; and last but not least opening the door to peace, reconciliation, reconstruction and development. For those providing humanitarian relief and protection: putting their principles into practice; demonstrating solidarity; contributing to their own and to global security; increased social and political cohesion of their own societies as positive actions become part of common bonds and conscience, often for several generations.

\section{HUMANITARIAN CRISES AND THE “FEAR OF THE OTHER”}

Today, political leaders, intellectuals, commentators and experts from all fields find the "fear of the other" as a convenient explanation and even justification for all the violence, the tensions, the wars and persecution that we witness in the world around us. Ethnic cleansing is supposedly the result of the fear of the other. Terrorism is due to the fear of the other. Jihad or crusades, political extremism, religious fundamentalism, all forms of racism, xenophobia can be ascribed to the fear of the others - to the eternal opposition of us and them, an eternal and eternally changing opposition. 
The fear of the others is an excuse for sins of commission, for sins of omission, for indifference when observing the worst crimes against humanity. The fear of the others is what allows the worst criminals to have a clear conscience that allows them to sleep at night and to go on vacation with their families.

Organized humanitarian action as it emerged from the $19^{\text {th }}$ and from the first half of the $20^{\text {th }}$ century was an expression of the liberal spirit of the age and also a response to the shortcomings of the world. Ethics and faith played and continue to play an important role in humanitarian action. However, humanitarian action is meant to bring out the positive in religion and not what divides. This is a very important issue at a time when religion appears to play a more important role again throughout the world, and once again both in a positive and in a negative sense.

On the positive side, one finds spiritual and ethical resources in religion. Also there is a sense of tolerance, freedom and even a friendly competition among religions - as long as their positive aspects come to the fore. At the same time, once more, religion is also being used as a tool of exclusion, intolerance and oppression: as a weapon against both "enemies" on the outside and as an instrument of control and oppression of one's own "faithful". Violence, discrimination, persecution, killings, torture in the name of religion, as well as in the name of ethnicity, have become daily occurrences of our time.

\section{HUMANITARIAN ACTION IS THE REVERSE OF THE “FEAR OF THE OTHER"}

The common feature of international humanitarian action is that it is essentially carried out for the benefit of others, of actual and potential victims who are not our fellow citizens, not citizens whom our state is ex officio expected to protect and to assist: they are others in the political, cultural, moral or ethical sense. They are threatened, they are suffering, often from the acts of their own governments or from the indifference or hostility of their own fellow citizens - while we are safe, we are protected and we have the resources. This contrast between the humanitarians, those who directly or indirectly are part of the humanitarian action broadly defined, on the one hand, and the actual and potential victims, on the other hand, is an essential feature of humanitarian action. Without understanding this contrast, this apparent opposition between "us" and "them", one cannot really begin to understand the nature and importance of humanitarian action.

Humanitarian action - the humanitarian imperative - is the exact reverse of the fear of the other. It is the reaching out across the divide. It is taking risks and accepting danger to help and protect the others. This is not just a moral imperative, it brings not only moral or ethical satisfaction - to individuals or entire communities and nations. By this one should not want to belittle the importance of the moral or ethical dimension of humanitarian action. However, one must emphasize that to provide relief and protection to the others - and this protection may extend to the definition under onerous and dangerous "responsibility to protect" - is also part of our political decisions, it is in our interests in the broadest sense of the word. 
It is through this radical difference from the "fear of the other" that we can say that "humanitarian action" is a source of hope for international order.

\section{THE INTERNATIONAL ORDER OF THE FUTURE - OPTIMISM IS THE ONLY REALISTIC OPTION}

International order has been evolving more rapidly than expected over the last fifteen years. One of the central questions of our time is the nature of the present and future international order. What is the direction of international order? Are we going towards greater threats or greater security? Are there new divisions to be expected between, on the one hand, those countries that can enjoy freedom, security, the respect for human rights and economic prosperity and, on the other hand, those that have to face strife and violence, wanton oppression and widespread poverty? Are we today at a turning point for the better or for the worse? What can we learn from the recent and the more distant past? What is the role of humanitarian action?

In recent years the need for large scale humanitarian action was brought home both by sudden, unexpected natural catastrophes - the Tsunami and the earthquake in Asia and Hurricane Katrina in America - and the continuation of man-made crises from Darfur to Iraq, from Afghanistan to Chechnia and Lebanon.

The principal common lessons of these crises was that there can be no relaxation in the readiness of the humanitarians and of the community at large to prevent crises and to help and protect victims when crises occur, and that humanitarian action and cooperation and humanitarian solidarity are among the most tangible expressions of the existence of an "international community".

International humanitarian action, even in situations where it is hard to carry out or remains below expectations, is one of the principal positive features of our globalized world. We wish that it should not be necessary, we wish that no man-made and no natural crises should occur in the future, and although we are ready, we wish that our readiness should not have to be turned into need to act. In fact, the constant pressure on the human and financial resources of humanitarian organizations across the board is a sign that governments and parliaments believe that through modern rigorous budget techniques one can plan away future humanitarian crises from occurring. Yet, humanitarian crises do occur and when they do occur they provide an important opportunity to demonstrate that international relations are not only about greed and conflict.

The history of the $20^{\text {th }}$ century, of the Second World War and more recently of the Cold War should teach us that when the situation in the world looks the most difficult and the most hopeless for peace, freedom and human rights, that these are the moments when there is the greatest need to overcome the temptation of pessimism and resignation: enlightened optimism becomes the only acceptable alternative.

Humanitarian action has three main broadly recognised objectives and effects: to protect and bring relief to the victims, to counteract violence and evil and to try to bring about a better world in the long run. 
Humanitarian action may stimulate solidarity in other areas and humanitarian action helps bring cohesion among those providing help and protection.

In today's world states remain the key players in international relations. However, the role of non-state actors has been greatly increasing - this is one of the principal objectives and consequences of globalization. Humanitarian action is one of the principal areas where private or non-state action has played a key role. Humanitarian action is a powerful antidote against nationalism, egotism, bureaucracy and intolerance. Actual or potential humanitarian action can become a powerful link among people around the world.

The single most important lesson that can be drawn from the period of the cold war and the years since the end of the cold war is that war has become less and less a workable solution to domestic or international problems. While there may be situations where the use of force is or appears to be inevitable for a just cause, it has become increasingly difficult to achieve even the most legitimate objectives through recourse to war.

There are numerous reasons for this: the nature of today's weapons, the reluctance of the populations of the democracies to accept the human and material sacrifices involved in war and the complex political and social contexts in which the use of force arises. This is not an argument for traditional pacifism or appeasement, which often assumed that any form of absence of war is peace, and that the use of force has to be avoided at any price.

The role of deterrence is to avoid conflict through the credible threat of the use of force. However, we have seen that the deterrence or threats from the "bad guys" have proven to be more credible than from the international community.

\section{FREEDOM AND SOLIDARITY - ESSENTIAL ELEMENTS OF INTERNATIONAL ORDER}

Optimism about the future is often decried as naivety, as idealism and as a lack of realism in the face of the human tendency towards conflict, violence and egoism. Yet, an enlightened optimism is the only realistic option when faced with the alternative. It is only an enlightened optimism that allows undertaking systematic efforts to combat the negative forces, to work for a "better world". History, the record of the $20^{\text {th }}$ century, show us that in the long run the forces of evil and oppression are on the losing side. No solid system can be built on anarchy, violence and destruction. The denial of freedom and of justice undermines the cohesion of any society.

There is today a marked pessimism especially among some of the humanitarians about the current state and the outlook for international order. Is there reason to be an optimist about the future of international order? Are the pessimists right? What are the contributions of humanitarian action to a better world, to a better international order?

All successful political and social orders are based on a combination of competition and solidarity, on upholding values and pursuing interests, and on 
affirming different identities and the respect of others of the different. The nature and the working of international order is determined, first of all, by the use or the non-recourse to force in the relations among states and the security of states and of citizens; second, by the nature of domestic systems and the way governments treat their own citizens - the respect for freedom and human rights; the third factor is the degree of freedom across borders and the degree of cooperation among states and non-state actors; and finally, by the degree of solidarity among the members of the international community, solidarity with respect to security, the basic economic resources and the defense of human dignity and human rights.

Globalization is a trend that has allowed unprecedented freedom of movement of goods, services, capital, technology and ideas in general across borders virtually among all the member nations of the United Nations. It has also contributed to the sustained growth of the world economy and a major boost to economic development. Increased competition within and between national economies is among the principal stimuli. However, one of the principal shortcomings of both the current theory and of the current practice of globalization is the lack of emphasis on and in some cases the total absence of solidarity as a complement or counterweight to competition. Yet, as mentioned above, all successful economic and social orders - national or international - have to include and balance competition and solidarity. Without one or the other, the order is likely to break down sooner or later, with major and lasting negative consequences.

In today's globalized world there is a widespread preoccupation that with the threat of communism and great power confrontation gone, new lasting divides, new sources of violence and fanaticism have emerged that divide nations and states into fortunate and unfortunate ones: on the one hand, societies that enjoy peace, freedom, stability, respect of human rights and economic prosperity, and, on the other hand, states and nations that suffer from oppression, violence, intolerance and low and declining living standards, and last but not least from serious humanitarian crises.

Humanism and humanitarianism alone cannot supply the complete framework and rules of an international order based on freedom, peace, justice and economic prosperity. However, the humanitarian agenda based on the principles of solidarity, of protection and of healing, of helping the victims of conflict and oppression or of natural disasters, of prevention and reconciliation, has to be an essential component of such an international order.

A broadly based international order inspired by humane values, rather than by intolerance, fanaticism, the search for power and domination, is in the interests of both large and small countries. To believe that development and consolidation of such an order, which corresponds to the principles of the original Atlantic Charter and of the Charter of the United Nations is not an illusion. In fact, such an order, based on the twin concepts of freedom and solidarity, has developed over the last sixty years among the nations of the Western world broadly defined. The worldwide implementation of these principles would mean for the first time a universal international order truly based on the principles of the UN Charter. 
Such an order, such a development is not only a possibility - it is a necessity for rich and poor countries alike.

\section{Notes}

1 Hieronymi, Otto and Jasson, Chiara: "Values and Interests as Motivation for Humanitarian Action", unpublished paper presented at the $43^{\text {rd }}$ Annual Convention of the International Studies Association, March 2002, New Orleans.

Otto Hieronymi, "A world-wide success of solidarity: the resettlement and integration of Hungarian refugees" Paper presented at a Conference organized by Webster University on the occasion of the $50^{\text {th }}$ Anniversary of the International Organisation for Migration and the $45^{\text {th }}$ anniversary of the Hungarian uprising of 1956 on "Migration and the International Community: From Hungary 1956 to the Tasks of Today" Geneva, 23 October 2001. 